\title{
Origin of the monoene fats in the lipid of midwater fishes: relationship between the lipids of myctophids and those of their prey
}

\author{
Hiroaki Saito*, Masakazu Murata \\ Laboratory of Lipid Chemistry (Lipid Chemistry Section), National Research Institute of Fisheries Science, \\ Minístry of Agriculture, Forestry and Fisheries, Fuku-ura, Kanazawa-ku, Yokohama-shi 236, Japan
}

\begin{abstract}
The lipid and fatty acid composition of the total lipids in the tissues (whole animal excluding stomach contents) and the stomach contents of 13 myctophid species living in the mesopelagic zone were analyzed. Triacylglycerols (TAG) were the dominant deposit lipids in 10 myctophid species, while wax esters (WE) were found to be the major neutral lipids in 3 non vertically migratory species. Lipids from the myctophid stomach contents were determined to contain mixtures of WE and TAG. Monoenoic acids and alcohols were the major fatty components in both the TAG and the WE of the lipids from the tissues and stomach contents of all of the specimens examined. Lipid classes in the stomach contents originating from prey were different from those in myctophid tussues, but the level of monoenes in stomach content lipids was very similar to those in the tissue lipids. Thus finding suggests that myctophids may transfer dietary lipids to specific lipid classes, without biosynthetic modification such as carbon chain elongation or desaturation.
\end{abstract}

KEY WORDS: Myctophidae - Monoene - Deep-sea fish Food chain - Fish oil - Lipid class · Fatty acid composition . Wax ester Triacylglycerol - Monoenoic fatty acid

\section{INTRODUCTION}

It is reported that pelagic surface fishes generally transform various lipid classes from their prey to triacylglycerols (TAG) as deposit lipids, and that their lipids contain high amounts of $\mathrm{n}-3$ polyunsaturated fatty acids (PUFA) (Ackman 1982, Hølmer 1989, Japan Aquatic Oil Association 1989, Morris \& Culkin 1989) Typically marine fish TAG contain useful n-3 fatty acids which are readily digested. Humans may efficiently adsorb lipids from these pelagic fishes and use them for nutritional purposes (Hepburn et al. 1986 Kinsella 1986, 1988, Ackman 1988, Carroll \& Woodward 1989, Harris 1989). Though the PUFA levels in the tissue (whole animal excluding stomach contents) lipids of marine fish species are generally comparatively high and fish oil is good for our health (Kinsella

\footnotetext{
•E-mail: hiroakis@nrifs.affrc.go.jp
}

1986, 1988, Ackman 1988, Carroll \& Woodward 1989), the fatty acid composition of the fish lipid varies between species, individuals, and habitat (Jangaard et al. 1967. Hardy \& Mackie 1969, Deng et al. 1976, Dubrow et al. 1976, Stansby 1981, Henderson et al. 1984, Enser 1991, Takama et al. 1994). It has been suggested that factors (environmental conditions) such as the lipid composition of the dietary species have a marked influence on the lipid composition of their predators (Tyler \& Pearcy 1975, Linko et al. 1985, Morris \& Culkin 1989, St. John \& Lund 1996), and this variation in lipid composition is a typical characteristic of marine organisms (Sargent et al. 1988, St. John \& Lund 1996). In contrast, the lipid composition of land plant oils and animal fats exhibits far less variation between species and also varies little between individuals (Enser 1991, Rossell 1991).

Deep-sea teleost fishes often have considerable amounts of wax esters (WE) as a substitute for TAG (Mori et al. 1966, Lewis 1967, Nevenzel 1969, Nevenzel 
et al. 1969, Benson \& Lee 1975, Sargent et al. 1977. 1983. Hayashi \& Takagi 1980, Nevenzel \& Menon 1980 , Buisson et al. 1982, Grigor et al. 1983, Sargent et al. 1983, Body et al. 1985, Takagi et al. 1985, Lee \& Patton 1989, Bakes et al. 1995). Though the results in these papers have described the lipid of deep-sea fishes as containing high amounts of WE, they have not mentioned the origin of these high WE levels or detailed the relationship between the tissue WE and habitat. Data concerning the ecology and the chemical components of deep-sea fishes is limited relative to other species. The deep-sea fish family Myctophidae is known as the most widespread mesopelagic deep-sea fish family in the world's oceans. They are also known to be an important prey for various marine animals, and their lipids, which may contain high amounts of WE, are an important energy source for their predators (Pearcy 1964, Nevenzel et al. 1969, Tyler \& Pearcy 1975).

Myctophids are abundant in the transition zone between the Oyashio (the cold current off the eastern Japanese coast) and the Kuroshio (the warm current running along the southern coast of Japan) in the northern Pacific Ocean. To assess the relationship between myctophids and their prey, the tissue and stomach content of 13 species of myctophids were analysed.

\section{MATERIALS AND METHODS}

Cruise and sampling gear. All specimens of myctophids were caught by a trawler (RV 'Daisanju-maru- sada-maru') belonging to the Japan Marine Fishery Resource Research Center at depths from 20 to $700 \mathrm{~m}$ between latitudes $36^{\circ} 25^{\prime}$ and $41^{\circ} 26^{\prime} \mathrm{N}$ and longitudes $141^{\circ} 45^{\prime}$ and $146^{\circ} 52^{\prime} \mathrm{E}$ in the northern subarctic Pacific Ocean from July 4 to 31,1995 . Samples were collected during 9 cruises. The sampling gear was a midwater trawl $(30 \mathrm{~m} \times 30 \mathrm{~m}$ effective mouth opening, $30.0 \mathrm{~mm}$ mesh), and it was generally towed for 30 min (at night) or 60 min (in daytime) at a speed of 3.5 knots. Salinity, temperature, and depth were profiled using an STD (model AFP-1000, Alec Electronics Co., Kobe, Japan).

Materials. Samples of myctophids 65 specimens of 13 species in total) are listed in Table 1 . The surface seawater temperatures were between 11.0 and $22.5^{\circ} \mathrm{C}$ $\left(16.1 \pm 0.1^{\circ} \mathrm{C}\right)$

All samples were frozen immediately, and kept frozen at $-40^{\circ} \mathrm{C}$ for 2 mo until extraction.

Lipid extraction and analysis of lipid classes. After measurement of biological data (body length, body weight, and the kind of organisms in the stomach; Table 1), each sample fish was dissected into tissue (whole animal excluding stomach contents) and stomach contents, which were separated from the stomach by scraping off its inner wall. Then each individual was minced and homogenized in a mixture of chloroform and methanol $(2: 1, v / v)$. A portion of the homogenized sample was extracted according to the Folch procedure (Folch et al. 1957). The crude total lipids were separated into classes on silicic acid columns, and quantitative analysis of the constituents of the lipids was carried out by gravimetric analysis of the columnchromatography fractions (Hanahan et al. 1957. Barron

Table 1. Mean $\pm \mathrm{SE}$ average lipid content (\% wet weight) of the tissues and stomach contents of myctophid fishes ( $\mathrm{n}=5 \mathrm{samples}$ ). Temperature is temperature at the trawl depth. For stomach contents, 'crustaceans' indicates residual exoskeletons of copepods, and 'red and black' indicates partly digested reddish oil and black eyeballs of crustaceans

\begin{tabular}{|c|c|c|c|c|c|c|c|c|}
\hline & \multicolumn{2}{|c|}{ Trawl depth } & \multirow{2}{*}{$\begin{array}{l}\text { Temper- } \\
\text { ature } \\
\left({ }^{\circ} \mathrm{C}\right)\end{array}$} & \multirow{2}{*}{$\begin{array}{l}\text { Length } \\
(\mathrm{cm})\end{array}$} & \multirow{2}{*}{$\begin{array}{l}\text { Weight } \\
\text { (g) }\end{array}$} & \multirow{2}{*}{$\begin{array}{l}\text { Lipids } \\
\qquad(\%)\end{array}$} & \multirow{2}{*}{$\begin{array}{l}\text { Lipids of } \\
\text { stomach } \\
\text { contents }(\%)\end{array}$} & \multirow{2}{*}{$\begin{array}{l}\text { Stomach } \\
\text { contents }\end{array}$} \\
\hline & Day & Night & & & & & & \\
\hline \multicolumn{9}{|l|}{ First group } \\
\hline Ceratoscopelus warmingi & $500-600$ & $50-100$ & $2.8-15.8$ & $8.0 \pm 0.2$ & $7.6+1.1$ & $14.3 \pm 3.4$ & 6.3 & Red and black \\
\hline Notoscopelus resplendens & - & $50-100$ & $11.4-15.8$ & $7.9 \pm 0.3$ & $6.8 \pm 1.1$ & $16.1 \pm 1.8$ & 3.5 & Crustaceans \\
\hline Notoscopelus japonicus & $500-600$ & $50-100$ & $2.2-10.9$ & $12.0 \pm 0.8$ & $26.6 \pm 5.9$ & $26.1 \pm 7.4$ & 7.6 & Red \\
\hline Symbolophorus californiensis & $300-500$ & $20-50$ & $2.2-10.9$ & $10.9 \pm 0.4$ & $19.1 \pm 2.6$ & $21.9 \pm 4.7$ & 2.8 & Crustaceans \\
\hline Diaphus theta & $400-500$ & $20-50$ & $1.5-6.3$ & $7.2 \pm 0.4$ & $5.5 \pm 1.9$ & $7.1 \pm 1.6$ & 5.8 & $\begin{array}{l}\text { Small deep-sea } \\
\text { fishes }\end{array}$ \\
\hline Diaphus gigas & $400-500$ & $200-300$ & $2.8-3.5$ & $13.3 \pm 2.2$ & $46.8 \pm 19.7$ & $17.1 \pm 2.9$ & 6.5 & Red and black \\
\hline Myctophum asperum & $400-500$ & - & $2.9-3.5$ & $7.3 \pm 0.2$ & $6.9 \pm 0.9$ & $10.8 \pm 4.3$ & 4.2 & Crustaceans \\
\hline Lampanyctus jordani & $400-700$ & $100-700$ & $2.0-5.0$ & $11.7 \pm 0.5$ & $21.7 \pm 3.9$ & $8.5 \pm 2.4$ & 7.7 & Red and black \\
\hline Lampanyctus festivus & $500-700$ & - & $3.2-4.5$ & $11.2 \pm 1.2$ & $14.2 \pm 4.0$ & $4.4 \pm 1.4$ & - & \\
\hline \multicolumn{9}{|l|}{ Second group } \\
\hline Protomyctophum thompsoni & $300-400$ & $300-400$ & $3.0-3.1$ & $4.9 \pm 0.5$ & $2.0 \pm 0.9$ & $10.2 \pm 3.7$ & 10.9 & Red and black \\
\hline Stenobrachius leucopsarus & $400-600$ & $400-600$ & $2.0-4.9$ & $8.5 \pm 0.7$ & $7.6 \pm 1.6$ & $17.3 \pm 1.6$ & 6.5 & Red and black \\
\hline Stenobrachius nannochir & $500-700$ & $400-700$ & $2.2-4.1$ & $9.9 \pm 0.7$ & $9.3 \pm 1.9$ & $17.9 \pm 1.3$ & 7.0 & Red and black \\
\hline Lampanyctus regalis & $500-700$ & $500-700$ & $2.2-3.9$ & $17.9 \pm 0.9$ & $59.2 \pm 10.4$ & $14.2 \pm 1.4$ & 2.2 & Red and black \\
\hline
\end{tabular}


\& Hanahan 1958). The first eluate (dichloromethane and $n$-hexane, $2: 3, \mathrm{v} / \mathrm{v}$ ) collected was the WE fraction The second eluate (dichloromethane) contained the TAG fraction. This was followed with dichloromethane and ether $(9: 1, v / v)$ eluting the sterols, dichloromethane and methanol $(9: 1, v / v)$ eluting the free fatty acids (FFA), and dichloromethane and methanol (5:1, $\mathrm{v} / \mathrm{v})$ and dichloromethane and methanol $(1: 20, \mathrm{v} / \mathrm{v})$ eluting the phospholipids (PL). Individual lipids separated from each lipid class were identified with authentic samples by comparison of $R_{f}$ values using thin layer chromatography (TLC) (Merck \& Co. Ltd, Kieselgel 60 , thickness of $0.25 \mathrm{~mm}$ for analysis) and characteristic peaks using nuclear magnetic resonance (NMR). All sample lipids were dried under argon at room temperature and stored at $-40^{\circ} \mathrm{C}$.

Preparation of methyl esters and gas-liquid chromatography (GLC). The individual components of TAG were converted to fatty acid methyl esters by direct transesterification with boiling methanol containing $1 \%$ of concentrated hydrochloric acid under reflux for $1.5 \mathrm{~h}$ (Japan Oil Chemists' Society 1990). The reaction mixture was poured into saturated brine and the organic compounds were extracted with $n$-hexane. The methyl esters thus obtained were purified by column chromatography with silica gel by elution of dichloromethane.

The WE fraction was converted to fatty acid methyl esters and fatty alcohols by the same procedure. The reaction products were separated by silicic acid column chromatography. The first fraction eluted by dichloromethane contained the purified fatty acid methyl esters, and the second fraction eluted by a mixture of dichloromethane and ether $(9: 1, v / v)$ contained the purified fatty alcohols.

The composition of the fatty acid methyl esters and fatty alcohols was determined by GLC using an HP 5890 series II gas chromatograph (Hewlett Packard Co., Yokogawa Electric Corporation, Tokyo, Japan) equipped with an omegawax-250 fused silica capillary column (30 $\mathrm{m} \times 0.25 \mathrm{~mm}$ inner diameter; $0.25 \mu \mathrm{m}$ film, Supelco Japan Co. Ltd, Tokyo, Japan). The temperatures of the injector and the column were held at 250 and $210^{\circ} \mathrm{C}$, respectively, and the split ratio was $1: 100$. Helium was used as the carrier gas with a constant inlet rate of $40 \mathrm{ml} \mathrm{min} \mathrm{m}^{-1}$ (Ohshima et al. 1989, Ratnayake \& Ackman 1989).

Quantitative analyses were performed on the capillary columns by means of a Shimadzu Model C-R5A (Shimadzu Seisakusho Co. Ltd, Kyoto, Japan) electronic integrator.

Peak identification. Fatty acid methyl esters and wax alcohols were identified using (1) marine lipid methyl esters as standards (omegawax test mixture No. 4-8476, Supelco Japan Co. Ltd), (2) semilogarithmic plots of rel- ative retention time (RRT) against carbon chain lengths of the fatty acids of fish oil and fitting the logarithm of RRT of the fatty acids onto these plots, comparing the equivalent chain length (ECL) values according to the method of Ackman (1989), and (3) comparison of gas chromatography mass spectrometry data (GC/MS, JMS-DX303, JEOL Co. Ltd, Tokyo, Japan) using the same capillary column. The injector and separation temperatures were 250 and $190^{\circ} \mathrm{C}$, and the ionization voltage was $70 \mathrm{eV}$. Some peaks of the important fatty alcohols, such as 20:1n-9 and 22:1n-9, were confirmed by GC/MS

NMR spectrometry. Spectra were recorded on a GSX-270 NMR spectrometer (JEOL Co. Ltd) in the pulsed Fourier transform mode at $270 \mathrm{MHz}$ in deuterochloroform solution using tetramethylsilane as an internal standard.

Statistical analyses. More than 3 replications were made of the samples for all treatments. The significant differences of means for the data were analysed by Student's $t$-test at the $\mathrm{p}<0.05$ level.

\section{RESULTS AND DISCUSSION}

\section{Habitat of the myctophid species and their lipid contents}

Nine myctophid species (first group in Table 1; Ceratoscopelus warmingi, Notoscopelus resplendens, Notoscopelus jäponicus, Symbolophorus californiensis, Diaphus theta, Diaphus gigas, Myctophum asperum, Lampanyctus jordani, Lampanyctus festivus) displayed diel vertical migration, as peak catches of these species occur in near-surface waters (20 to $200 \mathrm{~m}$ ) at night and in the mesopelagic zone (400 to $700 \mathrm{~m}$ ) during the day (Taylor 1968, Badcock \& Merrett 1976, Kawaguchi 1977) The 4 non migratory species (second group in Table 1; Protomyctophum thompsoni, Stenobrachius leucopsarus, Stenobrachius nannochir, and Lampanyctus regalis) were only caught in the mesopelagic zone (Table 1) (Pearcy 1964, Taylor 1968, Childress \& Nygaard 1973, Pearcy et al. 1977). Habitat temperatures $\left(1.5\right.$ to $\left.10.9^{\circ} \mathrm{C}\right)$ of these species were markedly lower than those captured at or near the surface $(11.0$ to $22.5^{\circ} \mathrm{C} ;$ mean \pm standard error: $\left.16.1 \pm 0.1^{\circ} \mathrm{C}\right)$. How ever, the vertical distributions of $C$. warmingi $(2.8$ to $15.8^{\circ} \mathrm{C}$ ) and $N$. resplendens $\left(11.4\right.$ to $\left.15.8^{\circ} \mathrm{C}\right)$ were not restricted to this water mass (Table 1 ).

The total lipid content and morphological data of the myctophids are shown in Table 1. The tissue lipids of all of the 13 species contained high ratios of neutral deposit lipids (4.4 to $26.1 \% ; 14.0 \pm 0.5 \%$ ) as compared with those of other fish species. For example, the levels of the tissue lipids of some representative marine fish 
Table 2. Mean $\pm \mathrm{SE}$ ( $\mathrm{n}=3$ samples) lipid group composition in tussue of 13 species of Myctophidae expressed as weight percent of total lipids

\begin{tabular}{|lccrrr|}
\hline & Wax esters & Triacylglycerols & Sterols & Free fatty acids & Phospholipids \\
\hline First group & & & & & \\
Ceratoscopelus warmingi & $0.3 \pm 0.1$ & $88.5 \pm 1.0$ & $3.1 \pm 0.5$ & $5.0 \pm 0.9$ & $3.1 \pm 0.3$ \\
Notoscopelus japonicus & $1.2 \pm 0.6$ & $87.3 \pm 2.2$ & $3.1 \pm 0.7$ & $3.7 \pm 3.0$ & $4.7 \pm 1.9$ \\
Notoscopelus resplendens & $0.8 \pm 0.2$ & $81.7 \pm 2.0$ & $5.8 \pm 0.8$ & $1.3 \pm 0.5$ & $10.5 \pm 2.4$ \\
Symbolophorus californiensis & $0.7 \pm 0.8$ & $92.3 \pm 1.1$ & $1.6 \pm 0.3$ & $3.2 \pm 1.5$ & $2.2 \pm 0.5$ \\
Diaphus theta & $2.7 \pm 1.1$ & $70.7 \pm 5.5$ & $5.8 \pm 1.5$ & $13.4 \pm 2.6$ & $7.4 \pm 1.4$ \\
Diaphus gigas & $0.4 \pm 0.1$ & $88.7 \pm 2.5$ & $3.8 \pm 1.2$ & $4.4 \pm 1.2$ & $2.8 \pm 1.1$ \\
Myctophum asperum & $1.0 \pm 1.1$ & $81.4 \pm 3.9$ & $7.8 \pm 2.3$ & $1.6 \pm 0.5$ & $8.3 \pm 1.6$ \\
Lampanyctus jordani & $1.5 \pm 0.1$ & $84.5 \pm 2.4$ & $3.1 \pm 0.8$ & $4.6 \pm 1.0$ & $6.3 \pm 1.4$ \\
Lampanyctus festivus & $1.5 \pm 1.2$ & $73.3 \pm 4.8$ & $7.0 \pm 5.9$ & $7.7 \pm 3.0$ & $10.5 \pm 8.8$ \\
Second group & $1.1 \pm 0.3$ & $85.3 \pm 1.6$ & $4.0 \pm 0.1$ & $6.4 \pm 0.5$ & $3.1 \pm 1.9$ \\
Protomyctophum thompsoni & $89.4 \pm 1.3$ & $5.6 \pm 1.4$ & $1.5 \pm 0.2$ & $1.8 \pm 0.2$ & $1.6 \pm 0.7$ \\
Stenobrachius leucopsarus & $87.3 \pm 6.3$ & $3.5 \pm 0.9$ & $1.3 \pm 0.3$ & $1.4 \pm 0.3$ & $6.4 \pm 5.6$ \\
Stenobrachius nannochir & $85.6 \pm 2.2$ & $9.0 \pm 3.1$ & $1.6 \pm 0.1$ & $2.3 \pm 0.8$ & $1.5 \pm 0.2$ \\
Lampanyctus regalis & & & & \\
aPurified sterol was immediately crystallized after isolation in almost all cases & & \\
\hline
\end{tabular}

species such as horse mackerel Trachurus japonicus, Japanese anchovy Engraulis japonicus, chum salmon Oncorhynchus keta, Alaska pollack Theragra chalcogramma, and yellowfin tuna Thunnus albacares were $2.9-12.8,0.5-9.8,1.6-5.7,0.4-0.7,0.5-4.8 \%$, respectively (Japan Aquatic Oil Association 1989, Morris \& Culkin 1989). A variety of partially digested small fish. and crustaceans (e.g. copepods) was found in the stomachs of the myctophids examined, and the mean stomach lipid content $(2.2$ to $7.6 \% ; 5.2 \pm 0.1 \%)$ was far lower than that of the tissue except for Lampanyctus jordani and Protomyctophum thompsoni. Therefore, we suggest that myctophids residing in subarctic seawater may actively accumulate most of their dietary lipids rather than use them as an energy source for vertical migration.

\section{Lipid composition of tissues and stomach contents}

The lipid group composition of myctophid tissues are shown in Table 2. The lipids of all species contained a large amount of neutral deposit lipid (89.5 to $98.5 \% ; 94.7 \pm 0.2 \%$ ), with a small amount of polar tissue lipid $(1.5$ to $10.5 \% ; 5.3 \pm 0.2 \%)$. In this study, the myctophid species may be divided into 2 types according to the kinds of neutral lipids in their tissues, and the ratios of the lipid class components in individuals of the same species were very similar to each other ( $p<0.05$; Table 2$)$. In the first type, TAG (70.7 to $92.3 \% ; 83.4 \pm 0.7 \%$ ) was the major constituent of neutral lipids (all of the first group and 1 species of the second group, Protomyctophum thompsoni; in
Table 2), with minor phospholipid levels and very small levels of WE $(0.3$ to $2.7 \% ; 1.1 \pm 0.1 \%)$.

Only 3 species (Stenobrachius leucopsarus, Stenobrachius nannochir, and Lampanyctus regalis in the second group) had WE $(85.6$ to $89.4 \% ; 87.4 \pm 0.6 \%)$ as a major component and glycerol derivatives as a minor component (Nevenzel et al. 1969a, Lee \& Patton 1989). The 3 myctophid species which contained high levels of WE had similar lipid class ratios and they were all non vertically migratory species. In contrast, the other 10 myctophid species, which had high TAG levels, displayed vertical migration - with the exception of Protomyctophum thompsoni (Tables $1 \& 2$ ). There may be a relationship between the high WE content in the neutral deposit lipids of myctophid tissues and non migratory behavior, as only the stationary fish species except for $P$. thompsoni have high levels of WE. The sterols (Table 2) were found at low levels (1.3 to $7.8 \%$; $3.8 \pm 0.2 \%$ ) in all samples. The purified sterols were immediately crystallized after isolation, and only the sterol fraction contained cholesterol-it was identified against authentic cholesterol using TLC and NMR. Hardly any hydrocarbons were detected in the specimens examined.

Although the myctophids examined were caught only during the summer season, we could analyze their prey items. The stomach content lipids of myctophids differ from their tissue lipids, as PL $(16.6 \pm 1.2 \%)$ and FFA $(24.9 \pm 1.0 \%)$ were major constituents in the stomach contents (Table 3 ). Based on the high levels of TAG $(83.4 \pm 0.7 \%)$ and WE $(87.4 \pm 0.6 \%)$ in tissue lipids, we suggest that the high ratio of FFA in stomach content lipids is a result of enzymatic degradation of glyceride 
Table 3. Lipid composition in stomach contents of 12 species of Myctophidae expressed as weight percent of total lipids

\begin{tabular}{|c|c|c|c|c|c|}
\hline & Wax esters & Triacylglycerols & Sterols & Free fatty acids & Phospholipids \\
\hline \multicolumn{6}{|l|}{ First group } \\
\hline Ceraloscopelus warmingi & 5.2 & 39.0 & 9.3 & 23.7 & 22.5 \\
\hline Notoscopelus resplendens & 5.2 & $44.6^{\mathrm{i}}$ & & 39.4 & 10.9 \\
\hline Notoscopelus japonicus & 27.4 & 35.5 & 13.2 & 19.2 & 4.7 \\
\hline Symbolophorus californiensis & 7.9 & 35.0 & 17.5 & 16.3 & 23.3 \\
\hline Diaphus theta & 26.5 & 21.3 & 7.6 & 21.8 & 22.8 \\
\hline Diaphus gigas ${ }^{\mathrm{b}}$ & 1.4 & 68.4 & 5.9 & 15.1 & 9.0 \\
\hline Myctophum asperum & 4.6 & $51.4^{\mathrm{d}}$ & & 38.1 & 5.6 \\
\hline \multicolumn{6}{|l|}{ Lampanyctus jordani } \\
\hline \\
\hline $\begin{array}{l}\text { Stenobrachius leucopsarus } \\
\text { Stenobrachius nannochirc }\end{array}$ & 5.7 & 22.9 & 10.5 & 21.9 & 39.0 \\
\hline Lampanyctus regalis & 23.9 & 21.2 & 15.0 & 28.3 & 11.6 \\
\hline
\end{tabular}

derivatives such as TAG and PL in the stomach (Patton et al. 1975). Moreover, the higher levels of PL in stomach content lipids is considered to be caused by low levels of the other lipid groups in the prey. PL is generally important as a membrane lipid of the cells. Its proportion in the tissues is relatively constant and its relative level in lean organisms is generally higher than that in fat ones (Morris \& Culkin 1989, Takama et al. 1994).

However, WE may be more readily digested in the stomachs of myctophids and the adsorption rates of the fatty alcohols may be much faster than those of other fats such as FFA, as the only major compound observed in their stomachs was decomposed FFA, with comparatively small levels of both undigested WE and TG. The free fatty alcohols, which are considered to be degradation products of WE, were hardly observed in the stomach contents.

Even though the digestion of WE may be slightly faster than that of TG and PL, the lipid classes of the residual stomach contents included varying levels of WE, TAG, FFA, and PL (Table 3), while those in the tissues of myctophids included only WE or TAG with characteristic levels according to species (Table 2). This finding suggests that the lipid classes of stomach contents may be affected by the digestion levels of their prey organisms, which consist of small fishes and crustaceans. The lipid class of myctophid tissues may be assumed to be characteristic of the species because they were independent of those in their stomach contents and almost constant within each species. This suggests that the myctophid species may transform various lipid classes from their prey to specific lipid classes, such as TAG and WE.

\section{Fatty acid and fatty alcohol compositions of WE, major components for 3 stationary myctophid species}

The fatty acids and alcohols of the WE in the 3 stationary myctophid species, Stenobrachius leucopsarus, Stenobrachius nannochir, and Lampanyctus regalis, are shown in Table 4 . The major components in the WE of all these species were the $16: 1 \mathrm{n}-7$ (4.6 to $12.2 \%$ ), $18: 1 \mathrm{n}-9(21.9$ to $41.0 \%), 18: 1 \mathrm{n}-7$ (3.8 to $7.3 \%), 20: 1 \mathrm{n}-11$ (5.6 to $17.7 \%$ ), $20: 1 \mathrm{n}-9$ (3.7 to $13.0 \%$ ), and $22: 1 \mathrm{n}-11$ (6.1 to $13.9 \%)$ fatty acids, and the $16: 0(3.1$ to $43.2 \%)$, $18: 1 \mathrm{n}-9(2.4$ to $6.4 \%), 20: 1 \mathrm{n}-11$ (3.1 to $14.5 \%), 20: 1 \mathrm{n}-9$ (2.2 to $6.2 \%), 22: 1 \mathrm{n}-11$ (11.4 to $46.7 \%$ ), and $22: 1 \mathrm{n}-9$ ( 4.0 to $5.6 \%$ ) fatty alcohols. The alcohols and acids in the WE were characterized by a predominance of even-carbon and monoenoic chains $(14: 0,16: 0,18: 0$, $16: 1 n-7, n-5,18: 1 n-9, n-7, n-5,20: 1 n-11, n-9, n-7$, $22: 1 n-11, n-9, n-7$, and $24: 1 n-9)$, and in particular, the respective amounts of other minor alcohols were either very small (less than $1 \%$ ) or not detected (Table 4). The total amount of the monoenes in the species was 79.2 to $87.1 \%(82.4 \pm 1.4 \%)$ for fatty acids and 37.2 to $90.4 \%$ $(62.8 \pm 8.8 \%)$ for fatty alcohols. The high monoene levels in the WE of the myctophid lipids was similar to that of other deep-sea fish species containing WE as major components. The same trend has been noted in reports on the lipids of deep-sea fishes (Mori et al. 1966, Nevenzel et al. 1969a, Sargent et al. 1977, 1983, Hayashi \& Takagi 1980, Nevenzel \& Menon 1980, Buisson et al. 1982, Grigor et al. 1983, Sargent et al. 1983, Body et al. 1985, Takagi et al. 1985, Lee \& Patton 1989, Bakes et al. 1995). 
Table 4. Mean \pm SE ( $n=3$ samples) fatty acid and alcohol composition in the wax esters of 3 stationary species in Myctophidae expressed as weight percent of total fatty acids and alcohols, respectively

\begin{tabular}{|c|c|c|c|c|c|c|}
\hline & \multicolumn{2}{|c|}{ Stenobrachius leucopsarus } & \multicolumn{2}{|c|}{ Stenobrachius nannochir } & \multicolumn{2}{|c|}{ Lampanyctus regalis } \\
\hline & Acid & Alcohol & Acid & Alcohol & Acid & Alcohol \\
\hline Total saturated & 1.8 & 55.8 & 4.3 & 33.6 & 3.6 & 4.6 \\
\hline $14: 0$ & $0.3 \pm 0.1$ & $8.1 \pm 4.1$ & $2.3 \pm 0.5$ & $9.5 \pm 3.0$ & $0.9 \pm 0.2$ & $0.2 \pm 0.0$ \\
\hline $15: 0$ & $0.1 \pm 0.0$ & $0.7 \pm 0.0$ & $0.1 \pm 0.0$ & $0.7 \pm 0.0$ & $0.3 \pm 0.4$ & \\
\hline $16: 0$ & $0.3 \pm 0.1$ & $43.2 \pm 2.8$ & $0.9 \pm 0.1$ & $21.6 \pm 4.2$ & $1.6 \pm 0.1$ & $3.1 \pm 0.6$ \\
\hline $17: 0$ & $0.8 \pm 0.1$ & $0.3 \pm 0.1$ & $0.7 \pm 0.1$ & $0.1 \pm 0.0$ & $0.3 \pm 0.0$ & \\
\hline 18:0 & $0.1 \pm 0.0$ & $3.2 \pm 0.8$ & $0.2 \pm 0.0$ & $1.4 \pm 0.2$ & $0.5 \pm 0.0$ & $1.2 \pm 0.0$ \\
\hline $20: 0$ & $0.2 \pm 0.0$ & $0.3 \pm 0.1$ & $0.1 \pm 0.1$ & $0.3 \pm 0.0$ & & $0.1 \pm 0.0$ \\
\hline Total monoenoic & 79.3 & 37.5 & 80.6 & 60.5 & 87.2 & 90.4 \\
\hline $14: 1$ & $0.1 \pm 0.1$ & $0.3 \pm 0.0$ & $0.1 \pm 0.1$ & $0.3 \pm 0.1$ & $0.1 \pm 0.0$ & \\
\hline $16: 1 n-7$ & $11.2 \pm 0.9$ & $2.6 \pm 1.0$ & $12.2 \pm 0.9$ & $1.9 \pm 0.2$ & $4.6 \pm 0.2$ & $2.5 \pm 0.6$ \\
\hline $16: 1 n-5$ & $0.6 \pm 0.0$ & $0.5 \pm 0.1$ & $0.9 \pm 0.0$ & $0.4 \pm 0.1$ & $0.2 \pm 0.1$ & $0.2 \pm 0.1$ \\
\hline $17: 1$ & $0.1 \pm 0.0$ & $0.5 \pm 0.0$ & $0.1 \pm 0.0$ & $0.4 \pm 01$ & $0.1 \pm 0.0$ & $0.2 \pm 0.0$ \\
\hline $18: 1 n-9$ & $41.0 \pm 6.3$ & $6.4 \pm 1.0$ & $21.9 \pm 3.5$ & $2.4 \pm 0.6$ & $25.8 \pm 0.7$ & $4.5 \pm 0.4$ \\
\hline $18: 1 n-7$ & $7.3 \pm 0.8$ & $2.2 \pm 0.6$ & $3.8 \pm 0.2$ & $0.9 \pm 0.2$ & $5.6 \pm 0.1$ & $1.3 \pm 0.1$ \\
\hline $18: 1 n-5$ & $0.9 \pm 0.0$ & $0.7 \pm 0.2$ & $1.7 \pm 0.3$ & $0.7 \pm 0.2$ & $0.8 \pm 0.1$ & $0.4 \pm 0.1$ \\
\hline $20: 1 n-11$ & $5.6 \pm 1.8$ & $3.1 \pm 0.7$ & $15.2 \pm 0.8$ & $11.0 \pm 0.6$ & $17.7 \pm 2.4$ & $14.5 \pm 1.3$ \\
\hline $20: 1 n-9$ & $3.7 \pm 0.6$ & $2.2 \pm 0.4$ & $6.5 \pm 1.0$ & $5.7 \pm 1.4$ & $13.0 \pm 1.3$ & $6.2 \pm 0.4$ \\
\hline $20: 1 n-7$ & $0.6 \pm 0.0$ & $0.4 \pm 0.1$ & $0.9 \pm 0.2$ & $0.7 \pm 0.1$ & $1.5 \pm 0.2$ & $1.1 \pm 0.1$ \\
\hline $22: 1 n-11$ & $6.1 \pm 3.2$ & $11.4 \pm 4.4$ & $13.9 \pm 3.3$ & $28.1 \pm 6.9$ & $13.7 \pm 1.8$ & $46.7 \pm 1.3$ \\
\hline $22: 1 n-9$ & $1.4 \pm 0.2$ & $4.0 \pm 2.2$ & $2.2 \pm 02$ & $4.0 \pm 0.2$ & $1.9 \pm 0.2$ & $5.6 \pm 0.5$ \\
\hline $22: 1 n-7$ & $0.1 \pm 0.0$ & $0.8 \pm 0.1$ & $0.3 \pm 0.1$ & $1.3 \pm 0.3$ & $0.3 \pm 0.0$ & $2.5 \pm 0.3$ \\
\hline $24: 1 n-9$ & $0.6 \pm 0.1$ & $2.4 \pm 0.3$ & $0.9 \pm 0.1$ & $2.7 \pm 0.1$ & $1.9 \pm 0.2$ & $4.7 \pm 0.4$ \\
\hline Total polyenoic & 1.5 .6 & 0.5 & 10.3 & 0.5 & 6.0 & 0.1 \\
\hline $16: 2 n-6$ & $3.0 \pm 1.1$ & $0.3 \pm 0.1$ & $2.1 \pm 0.2$ & $0.2 \pm 0.0$ & $0.4 \pm 0.0$ & \\
\hline $18: 2 n-6$ & $2.5 \pm 0.6$ & $0.2 \pm 0.0$ & $1.8 \pm 0.0$ & $0.3 \pm 0.0$ & $1.4 \pm 0.1$ & $0.1 \pm 0.1$ \\
\hline $20: 4 n-6$ & $0.3 \pm 0.0$ & & $0.1 \pm 0.0$ & & $0.2 \pm 0.0$ & \\
\hline $18: 3 n-3$ & $1.2 \pm 0.3$ & & $0.9 \pm 0.2$ & & $0.3 \pm 0.1$ & \\
\hline $18: 4 n-3$ & $1.4 \pm 0.7$ & & $1.1 \pm 0.4$ & & $0.2 \pm 0.0$ & \\
\hline $20: 4 n-3$ & $0.8 \pm 0.3$ & & $0.5 \pm 0.3$ & & $0.6 \pm 0.0$ & \\
\hline $20: 5 n-3$ & $3.5 \pm 2.4$ & & $1.7 \pm 0.7$ & & $1.3 \pm 0.2$ & \\
\hline $22: 5 n-3$ & $0.3 \pm 0.1$ & & $0.3 \pm 0.1$ & & $0.3 \pm 0.1$ & \\
\hline $22: 6 n-3$ & $2.6 \pm 1.2$ & & $1.8 \pm 0.8$ & & $1.3 \pm 0.1$ & \\
\hline
\end{tabular}

Fatty acid composition of TAG, major components for 10 myctophid species which displayed vertical migration

The fatty acid composition of the TAG in the lipids of 10 species of myctophids which displayed vertical migration and that of Lampanyctus regalis ( $\mathrm{TAG}_{i} 9 \%$ of the total lipids) is shown in Table 5. The major components in the TAG of all of the species were 16:0 (17.0 $\pm 0.3 \%), 16: 1 \mathrm{n}-7(4.9 \pm 0.1 \%), 18: 0(4.2 \pm 0.2 \%), 18: 1 \mathrm{n}-$ $9(24.2 \pm 0.6 \%), 18: 1 \mathrm{n}-7(3.8 \pm 0.1 \%), 20: 1 \mathrm{n}-11(4.4 \pm$ $0.3 \%), 20: 1 \mathrm{n}-9(3.9 \pm 0.2 \%), 22: 1 \mathrm{n}-11(6.2 \pm 0.4 \%)$. $20: 5 n-3$ (icosapentaenoic acid, EPA) $(5.7 \pm 0.1 \%)$ and 22:6n-3 (docosahexaenoic acid, DHA) $(6.6 \pm 0.2 \%$ ). Similar to the case in the WE-rich species (Table 4), the total amount of monoenoic acids was also more than $50 \%(52.3 \pm 0.7 \%)$ of the total fatty acids in the $\mathrm{TAG}_{\text {, }}$ which was the major constituent in the tissues of the migratory myctophid species (Table 5). This presence of high levels of monoene fats in myctophid tissue lipids is markedly different from that of other marine fish species, which generally contain high amounts of n-3 PUFA (Japan Aquatic Oil Association 1989, Morris \& Culkin 1989).

\section{Fatty acid composition of the neutral deposit lipids in the myctophid prey}

The fatty acid and alcohol compositions of the TAG and WE in the neutral deposit lipids of the stomach contents of 12 species of Myctophids are shown in Tables $6 \&$ 7. (Lampanyctus festivus was not analyzed because there was nothing present in its stomach.) Three species, Notoscopelus japonicus, Diaphus theta, and Lampanyctus regalis, contained both WE and TAG as major components (Table 3); the fatty acid and alcohol compositions of WE were also ana- 


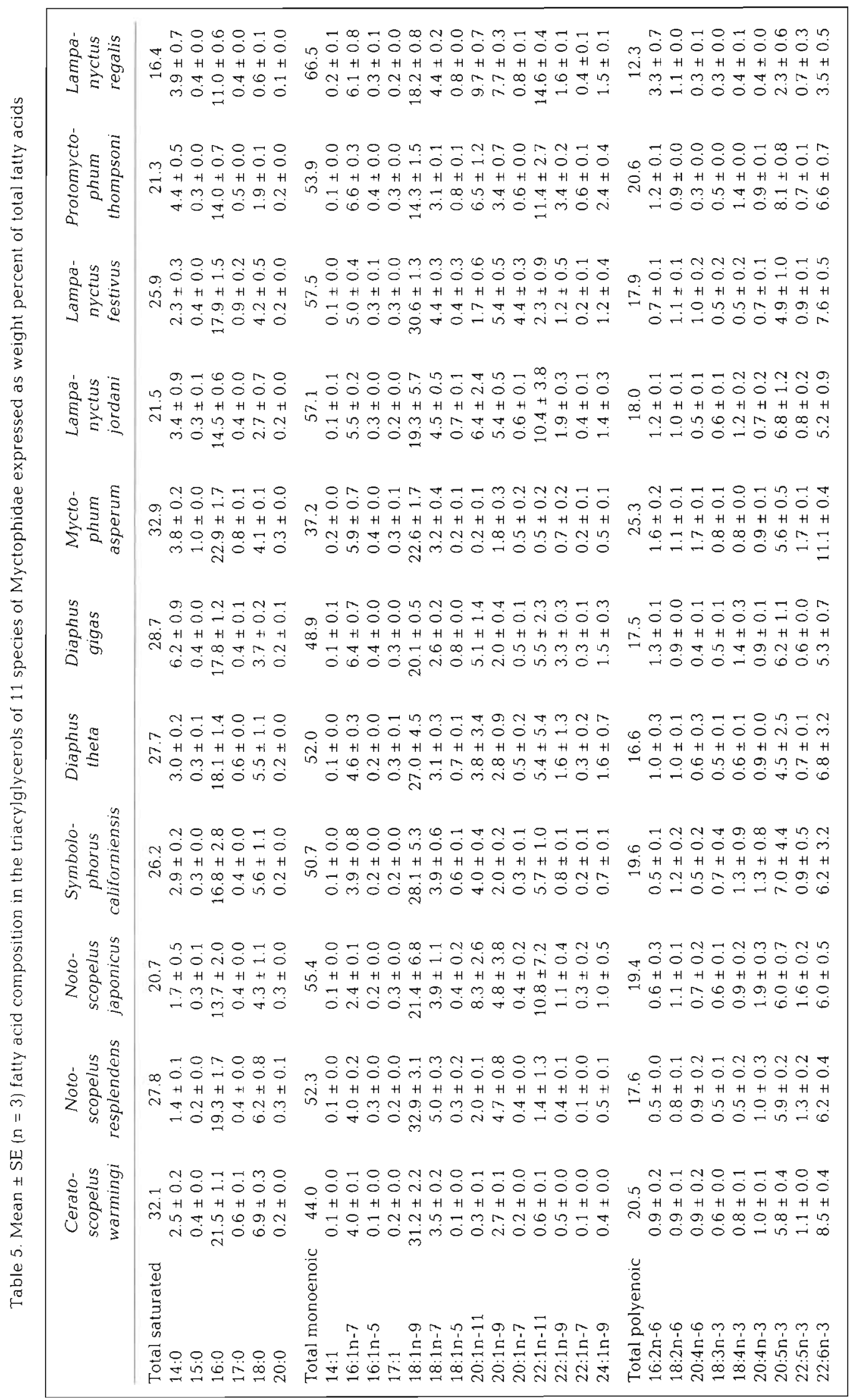




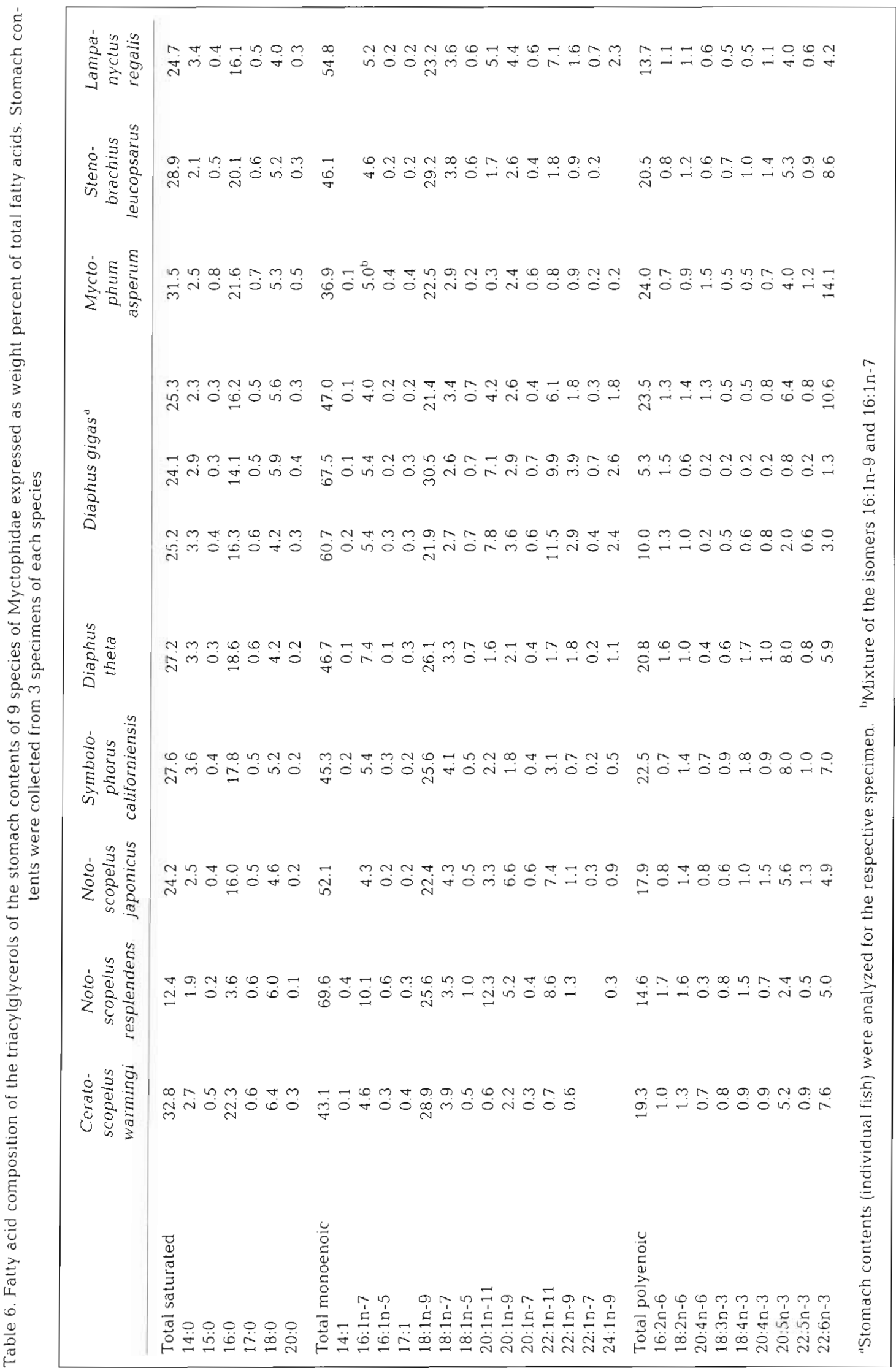


lyzed (Table 7). The total lipids of 3 samples (Lampanyctus jordani, Protomyctophum thompsoni, and Stenobrachius nannochir) were directly esterified (Table 7 ) because of the small lipid recovery levels (Table 3). Of these 3 species, only stomach contents of the $S$. nannochir contained both acids and alcohols. In all of the specimen stomach contents, the major fatty acids were $16: 0$ (2.4 to $22.3 \%), 16: 1 n-7$ (3.2 to $11.3 \%), 18: 1 \mathrm{n}-9 \quad(3.8$ to $34.4 \%), 20: 1 \mathrm{n}-9 \quad(0.6$ to $12.3 \%), 22: 1 n-11(1.2$ to $11.5 \%), 20: 5 n-3 \quad(4.0$ to $15.9 \%)$, and $22.6 \mathrm{n}-3(1.3$ to $14.1 \%)$ in the TAG and $\mathrm{WE}$, and the major fatty alcohols were 16:0 (2.8 to
$25.2 \%), 20: 1 \mathrm{n}-11$ (2.9 to $10.8 \%), 20: 1 \mathrm{n}-9$ (1.4 to $22.7 \%)$, and $22: 1 \mathrm{n}-11(7.0$ to $32.9 \%)$ in the WE. In almost all of the stomach content lipids, 18:1n-9 was the dominant fatty acid, and the 2 monoenoic acids 20:1n-9 and 22:1n-11 were the other major components in the total fatty acids of the stomach contents. The level of total monoene fatty acids in the TAG and WE reached 36.9 to $69.6 \%(51.9 \pm 0.6 \%)$ of the total fatty acids - with the exception of the acids in WE of N. japonicus (Tables $6 \& 7$ ). Total monoene fatty alcohols in the WE $(42.9$ to $71.4 \% ; 55.9 \pm 4.2 \%)$ were also found to be high (Table 7 ).

Table 7. Fatty acid and alcohol compositions of the wax esters and total lipids in the stomach contents ( $\mathrm{n}=3$ samples) in Myctophidae expressed as weight percent of total fatty acids and fatty alcohols, respectively

\begin{tabular}{|c|c|c|c|c|c|c|c|c|c|c|}
\hline & \multicolumn{2}{|c|}{$\begin{array}{c}\text { Notoscopelus } \\
\text { japonicus }\end{array}$} & \multicolumn{2}{|c|}{$\begin{array}{c}\text { Diaphus } \\
\text { theta }^{\circ}\end{array}$} & \multicolumn{2}{|c|}{$\begin{array}{l}\text { Lampa- } \\
\text { nyctus } \\
\text { regalis }\end{array}$} & \multirow{2}{*}{$\begin{array}{l}\text { Lampa- } \\
\text { nyctus } \\
\text { jordanib } \\
\quad \text { Acid }\end{array}$} & \multirow{2}{*}{$\begin{array}{l}\text { Protomycto- } \\
\text { phum } \\
\text { thompsonib } \\
\text { Acid }\end{array}$} & \multicolumn{2}{|c|}{$\begin{array}{c}\text { Steno- } \\
\text { brachius } \\
\text { nannochir }\end{array}$} \\
\hline & Acid & Alcohol & Acid & Alcohol & Acid & Alcohol & & & Acid & Alcohol \\
\hline Total saturated & 28.4 & 15.0 & 8.9 & 50.5 & 24.5 & 5.5 & 30.1 & 25.2 & 21.8 & 13.4 \\
\hline $14: 0$ & 12.5 & 3.5 & 5.1 & 23.5 & 3.4 & 0.3 & 4.2 & 2.6 & 2.4 & 2.8 \\
\hline $15: 0$ & 0.7 & 1.1 & 0.1 & 0.5 & 0.4 & 0.7 & 0.5 & 0.4 & 0.4 & 1.3 \\
\hline $16: 0$ & 6.0 & 6.8 & 2.9 & 25.2 & 16.1 & 2.8 & 19.5 & 16.5 & 13.8 & 6.9 \\
\hline $17: 0$ & 1.1 & 2.4 & 0.4 & 0.2 & 0.5 & 0.3 & 0.6 & 0.5 & 0.5 & 1.3 \\
\hline $18: 0$ & 4.5 & 0.8 & 0.3 & 0.8 & 4.0 & 1.0 & 5.0 & 4.9 & 4.4 & 0.8 \\
\hline $20: 0$ & 3.6 & 0.4 & 0.1 & 0.3 & 0.1 & 0.4 & 0.4 & 0.3 & 0.3 & 0.4 \\
\hline Total monoenoic & 20.6 & 60.5 & 52.9 & 42.9 & 54.7 & 71.4 & 48.7 & 45.0 & 53.0 & 48.8 \\
\hline $14: 1$ & 0.6 & 0.7 & 0.2 & 0.6 & 0.1 & 0.4 & 0.2 & & 0.1 & 0.7 \\
\hline $16: 1 n-7$ & 3.2 & $8.8^{d}$ & 11.3 & 0.3 & 5.2 & 4.3 & 5.2 & 4.4 & 5.8 & $5.9^{d}$ \\
\hline $16: 1 n-5$ & 1.6 & 3.9 & 0.1 & 2.1 & 0.2 & 0.4 & 0.3 & 0.3 & 0.4 & 0.3 \\
\hline $17: 1$ & 2.5 & 0.3 & & & 0.2 & 0.4 & 0.3 & 0.2 & 0.2 & 0.3 \\
\hline $18: 1 n-9$ & 3.8 & 2.9 & 34.4 & 0.9 & 23.2 & 3.8 & 24.0 & 24.1 & 22.6 & 3.8 \\
\hline $18: 1 n-7$ & 0.8 & 2.0 & 2.1 & 2.0 & 3.6 & 1.2 & 3.3 & 4.3 & 3.6 & 1.7 \\
\hline $18: 1 n-5$ & 0.0 & 0.7 & 0.4 & 1.1 & 0.6 & 0.5 & 0.7 & 0.6 & 0.9 & 0.6 \\
\hline $20: 1 n-11$ & 2.8 & 2.9 & 1.7 & 10.8 & 5.1 & 10.4 & 3.3 & 2.7 & 6.6 & 4.3 \\
\hline $20: 1 n-9$ & $0.9^{d}$ & $22.7^{d}$ & 1.2 & 1.4 & 4.4 & 5.8 & 3.1 & 3.4 & 4.2 & $13.8^{\mathrm{d}}$ \\
\hline $20: 1 n-7$ & & & 0.1 & 0.6 & 0.6 & 1.1 & 0.5 & 0.5 & 0.6 & \\
\hline $22: 1 n-11$ & 3.3 & 12.8 & 1.2 & 7.0 & 7.1 & 32.9 & 4.9 & 3.4 & 6.5 & 15.7 \\
\hline $22: 1 n-9$ & 1.1 & 1.3 & 0.3 & 14.6 & 1.6 & 5.3 & 1.5 & 0.9 & $\hat{1} .4$ & \\
\hline $22: 1 n-7$ & 0.0 & 0.0 & & 0.0 & 0.7 & 1.9 & 0.1 & 0.2 & 0.2 & \\
\hline $24: 1 n-9$ & & 1.5 & & 1.6 & 2.3 & 3.0 & 1.2 & & & 1.8 \\
\hline Total polyenoic & 24.9 & 3.6 & 31.5 & 0.7 & 13.6 & 1.8 & 16.7 & 24.7 & 20.8 & 7.2 \\
\hline $16: 2 n-6$ & 0.7 & 0.6 & 2.5 & 0.6 & 1.1 & 1.4 & 1.2 & 1.0 & 1.2 & 3.9 \\
\hline $18: 2 n-6$ & 3.3 & 3.0 & 1.3 & 0.1 & 1.1 & 0.4 & 1.2 & 1.2 & 1.2 & 3.4 \\
\hline $20: 4 n-6$ & 0.6 & & 0.4 & & 0.6 & & 0.5 & 1.4 & 0.6 & \\
\hline $18: 3 n-3$ & 0.4 & & 0.5 & & 0.5 & & 0.5 & 0.5 & 0.6 & \\
\hline $18: 4 n-3$ & 6.1 & & 2.5 & & 0.5 & & 1.3 & 0.9 & 0.9 & \\
\hline $20: 4 n-3$ & 4.8 & & 1.8 & & 1.1 & & 0.8 & 0.7 & 0.7 & \\
\hline $20: 5 n-3$ & 4.7 & & 15.9 & & 4.0 & & 5.1 & 8.0 & 5.7 & \\
\hline $22: 5 n-3$ & 1.3 & & 1.1 & & 0.6 & & 0.6 & 0.9 & 0.7 & \\
\hline $22: 6 n-3$ & 3.0 & & 5.6 & & 4.2 & & 5.6 & 10.0 & 9.2 & \\
\hline $\begin{array}{l}{ }^{a} \text { Fatty acid and al } \\
\text { bFatty acid compo } \\
\text { Total lipids of th } \\
\text { contained both }\end{array}$ & $\begin{array}{l}\text { comp } \\
\text { ms of th } \\
\text { mach } \\
\text { lester }\end{array}$ & $\begin{array}{l}\text { ositions of } \\
\text { e total lip } \\
\text { ontents w } \\
\text { and alcol }\end{array}$ & max e & $\begin{array}{l}\text { ters } \\
\text { wax este }\end{array}$ & pecause & the react & mixture & of the acidic tr & inseste & ification \\
\hline dMixture of the is & $\operatorname{ssn}-7 a$ & nd $n-9$ fa & & & & & & & & \\
\hline
\end{tabular}




\section{Relationship between the fatty acid and alcohol compositions of the myctophids and those of their prey}

Residues of the exoskeletons and reddish ouls of copepods and the undigested black eyeballs of crustaceans were observed in the stomachs of the myctophids examined. Because both the WE and TAG in the stomach contents contained comparatively high ratios of monoene fats $(51.9 \pm 0.6 \%)$, similar to those in the tissue lipids of myctophids $(52.3 \pm 0.7 \%)$, there may be a relationship between the high total monoene contents in stomach contents and those in the myctophid tissue lipids. This result suggests that the high monoene content of the myctophids might result from its prey such as copepods, which live in a wide range from the deep sea to the surface in the subarctic zone of the northern sea area. In general, the myctophids may simply incorporate prey lipids in their tissues as fatty acids and alcohols.

Total monoene levels of Stenobrachius nannochir $(80.6 \%$ for the acids and $60.5 \%$ for the alcohols) and Lampanyctus regalis $187.2 \%$ for the acids and $90.4 \%$ for the alcohols) are much higher than those of the prey $153.0 \%$ and $54.7 \%$ for the acids, and $48.8 \%$ and $71.9 \%$ for the alcohols, respectively), as shown in Tables $4 \&$ 7 The 2 stationary species rich in WE may accumulate the monoene fats as the acids and alcohols. On the other hand, the total monoene levels of the fatty acids in the tissue of Stenobrachius leucopsarus $179.3 \%$ in Table 4) was high, while those of the fatty alcohols was low $(37.5 \%$ in Table 4 ) compared to those of the prey (46.1\% in Table 6). Therefore, in the case of the species $S$. leucopsarus, the monoene fats may be accumulated only in the fatty acids. There may be a specificity of species in the fatty acid composition because there is a little difference between the monoene levels of the tissues in the 3 stationary species and those of their prey.

\section{Origin of monoene fats in the lipids of midwater fishes}

It is well known, from many reports on marine fishes, that comparatively high levels of n-3 PUFA are found in the lipids of almost all of the pelagic surface fish species, which mainly accumulate TAG as a neutral deposit lipid (Ackman 1982, Hølmer 1989, Japan Aquatic Oil Association 1989, Morris \& Culkin 1989). In the grazing food chain, pelagic surface fish have tendencies toward the accumulation of n-3 PUFA, which may originate from the phytoplankton and are essential for all marine fishes (Kanazawa et al. 1979, Yamada et al. 1980, Bell et al. 1986, Teshima et al.
1992, Furuita et al. 1996, Takeuchi et al. 1996). Levels of PUFA may gradually increase over time with predatory feeding in the sea, and high PUFA levels in the lipids of highly migratory fishes are often observed (Medina et al. 1995, Saito et al. 1995, Murase \& Saito 1996).

Copepods, which are known as primary consumer which prey on phytoplankton and small zooplankton and which generally have low ratios of PUFA in the WE of their tissue lipids, are the most important prey on the basis of biomass (Raymont 1963, Nevenzel 1969, Benson \& Lee 1975, Falk-Petersen et al. 1987, Ohman 1987). Many copepods species often contain large amounts of WE as energy reserves instead of TAG, and n-3 PUFA are not generally major constituents in WE - rather the monoene fats are (Lewis 1967, Lee et al. 1969, 1971, Gatten \& Sargent 1973, Lee \& Hirota 1973, Lee \& Barnes 1975, Sargent \& Lee 1975, Sargent et al. 1977, Falk-Petersen et al. 1987 , Joseph 1989, Kattner et al. 1989, Graeve \& Kattner 1992). The myctophids examined feed mainly on copepods, and in particular, on copepod species living in the deep sea and boreal sea which accumulde WE (Gorelova 1974, Benson \& Lee 1975, Tyler \& Pearcy 1975, Hopkins \& Baird 1977). For example, in the report of Tande \& Henderson (1988), the lipid of Calanus glacialis had a high level of WE. Ohman et al. (1989) also reported a high WE content in the lipid of Neocalanus tonsus. Furthermore, the lipids of Calanus hyperboreus and Calanus finmarchius contained high levels of WE rich in monoene fats (Graeve \& Kattner 1992). It is proposed that WE-derived constituents from lipid-rich copepods of the genera Neocalanus and Eucalanus may be incorporated in the lipids of myctophid tissues, because there were some copepods like calanoids in the stomachs of the myctophids examined (Table 1).

Although the lipid composition in the myctophid tissues examined was nearly constant within species ( $\mathrm{p}<$ 0.05 ) and different from those in their prey, which contained various ratios of classes of neutral and polar lipids, the fatty acid and alcohol compositions of the myctophid lipids were mainly composed of monoenes which were very similar to those of their prey. These results suggest that myctophids may transform various lipid classes of their prey to the specific class (TAG in 10 species and WE in 3 species), without biosynthetic modification - such as carbon chain elongation and desaturation of fats

Consistently high amounts of monoenoic fats were also found in the neutral deposit lipids of some pelagic surface fish species such as saury (Ota et al. 1980), capelin, and herring (Ratnayake \& Ackman 1979a, b, Linko et al. 1985), whose lipids originate from prey such as zooplankton (Pascal \& Ackman 1976, Rat- 
nayake \& Ackman 1979a, b). These authors pointed out that the planktonic fatty alcohols are assimilated efficiently and converted directly to fatty acids in the above pelagic fish species. Myctophid species may prey on similar plankton to these pelagic fishes, as the fats of all the myctophids examined contained 18:1, $20: 1$, and 22:1 carbon chains, which is very similar to those of the pelagic fish species. It is suggested that the feeding habits of these 13 species of myctophids caught in the transition zone between the Oyashio and Kuroshio currents may be similar to each other and to those of the pelagic fish species such as saury caught in the same area.

We conclude that the lipids in the myctophids caught in the oceanic front of the cold Oyashio current in northern Pacific Ocean contained high amounts of monoenes, especially 18:1,20:1 and 22:1 and that these were the dominant fats for both TAG and WE in the lipids of all samples with PUFA found only in small amounts. It is suggested that the high monoene content of the lipids of myctophids may be considered as characteristic of this family.

Acknowledgements. This work was supported by grants from Marino-Forum 21 Project 'Technical Development of Utilization of Myctophidae Fish Resources.' We thank the Japan Marine Fishery Resource Research Center for donating all the specimens which made this work possible. We also thank Ms Yuko Uesugi for valuable technical assistance. We are indebted to Prof. Hiroshi Kawaguchi, Ocean Research Institute, Tokyo University, for identification of the myctophid samples used.

\section{LITERATURE CITED}

Ackman RG (1982) Fatty acid composition of fish oils. In: Barlow SM, Stansby ME (eds) Nutritional evaluation of longchain fatty acids in fish oil. Academic Press, London, $p$ $25-88$

Ackman RG (1988) Concerns for utilization of marine lipids and oils. Food Technol 42:151-155

Ackman RG (1989) WCOT (capillary) Gas-liquid chromatography. In: Hamilton RJ, Rossell JB (eds) Analysis of oils and fats. Elsevier Appl Sci Publishers, London, p 137-172

Badcock J, Merrett NR (1976) Midwater fishes in the eastern North Atlantic-I. Vertical distribution and associated biology in $30^{\circ} \mathrm{N}, 23^{\circ} \mathrm{W}$, with developmental notes on certain myctophids. Prog Oceanogr 7:3-58

Bakes MJ, Elliott NG, Green GJ, Nichols PD (1995) Variation in lipid composition of some deep-sea fish (Teleostei: Oreosomatidae and Trachichthyidae). Comp Biochem Physiol $111 \mathrm{~B}: 633-642$

Barron EJ, Hanahan DJ (1958) Observations on the silicic acid chromatography of the neutral lipids of rat liver, beef liver, and yeast. J Biol Chem 231:493-503

Bell MV, Henderson RJ, Sargent JR (1986) The role of polyunsaturated fatty acids in fish. Comp Biochem Physiol 83B: $711-719$

Benson AA, Lee RF (1975) The role of wax in oceanic food chains. Sci Am 232:77-83

Body DR, Johnson CB, Shaw GJ (1985) The monounsaturated acyl- and alkyl- moieties of wax esters and therr distribution in commercial orange roughy (Hoplostethus atlanticus) oil. Lipids 20.680-684

Buisson DH, Body DR, Dougherty GJ, Eyres L, Vlieg P (1982) Oil from deep water fish species as a substitute for sperm whale and jojoba oils. J Am Oil Chem Soc 59:390-395

Carroll KK, Woodward CJH (1989) Nutrition and human health aspects of marine oils and lipids. In: Ackman RG (ed) Marine biogenic lipids, fats, and oils Vol 11. CRC Press Inc, Boca Raton, FL, p 435-456

Childress JJ, Nygaard MH (1973) The chemical composition of midwater fishes as a function of depth of occurrence off Southern California. Deep Sea Res 20:1093-1109

Deng JC, Orthoefer FT, Dennison RA, Watson M (1976) Lipıds and fatty acids in mullet (Mugil cephalus): seasonal and locational variations. J Food Sci 41:1479-1483

Dubrow D, Hale M, Bimbo A (1976) Seasonal variations in chemical composition and protein quality of menhaden. Mar Fish Rev 38:12-16

Enser MB (1991) Animal carcass fats and fish oils. In: Rossell JB. Pritchard JLR (eds) Analysis of oilseeds, fats and fatty foods. Elsevier Appl Sci Publishers, London, p 329-394

Falk-Petersen S, Sargent JR, Tande KS (1987) Lipid composition of zooplankton in relation to the sub-arctic food web. Polar Biol 8:115-120

Folch J, Lees M, Stanley GH (1957) A simple method for the isolation and purification of total lipids from animal tissues. J Biol Chem 226:497-509

Furuita $H$, Takeuchi $T$, Watanabe $T$, Fujimoto $H$, Sekiya $S$, Imaizumi K (1996) Requirements of larval yellowtail for eicosapentaenoic acid, docosahexaenoic acid, and n-3 highly unsaturated fatty acid. Fish Sci 62:372-379

Gatten RR, Sargent JR (1973) Wax ester biosynthesis in calanoid copepods in relation to vertical migration. Neth $J$ Sea Res 7:150-158

Gorelova TA (1974) Zooplankton from the stomachs of juvenile lantern fish of the family Myctophidae. Oceanol Wash 14:575-580

Graeve M, Kattner G (1992) Species-specific differences in intact wax esters of Calanus hyperboreus and $C$. finmarchicus from Fram Strait-Greenland Sea. Mar Chem 39:269-281

Grigor MR, Thomas CR, Jones PD, Buisson DH (1983) Occurrence of wax esters in the tissues of the orange roughy (Hoplostethus atlanticus). Lipids 18:585-588

Hanahan DJ, Dittmer JC, Warashina E (1957) A column chromatographic separation of classes of phospholipides. J Biol Chem 228:685-700

Haque A, Pettersen J, Larsen T, Opstvedt J (1981) Fishmeal and oil from lantern fish (Myctophidae) with special emphasis on protein quality. I Sci Food Agric 32:61-70

Hardy R, Mackie P (1969) Seasonal variation in some of the lipid components of sprats (Sprattus sprattus). J Sci Food Agric 20:193-198

Harris WS (1989) Fish oils and plasma lipid and lipoprotein metabolism in humans: a critical review. J Lipid Res 30 : $785-807$

Hayashi K, Takagi T (1980) Occurrence of unusually high level of wax esters in deep-sea teleost fish muscle, Hoplostethus atlaticus. Bull Jpn Soc Sci Fish 46:459-463

Henderson RJ, Sargent RJ, Hopkins CCE (1984) Changes in the content and fatty acid composition of lipid in an isolated population of the capelin Mallotus villosus during sexual maturation and spawning. Mar Biol 78:255-263

Hepburn FN, Exler J, Weihrauch JL (1986) Provisional tables on the content of omega- 3 fatty acids and other fat components of selected foods. J Am Diet Assoc 86:788-793 
Hølmer G (1989) Triglycerides, In: Ackman RG (ed) Marine biogenic lipids, fats, and oils Vol I. CRC Press Inc, Boca Raton, FL, p 139-174

Hopkins TL, Baird RC (1977) Aspects of the feeding ecology of oceanic midwater fishes. In: Andersen NR, Zahuranec BJ (eds) Oceanic sound-scattering prediction. Plenum Press, New York, p 325-360

Jangaard PM, Ackman RG, Sipos JC (1967) Seasonal changes in fatty acid composition of cod liver, flesh, and milt lipids. J Fish Res Bd Can 24:613-627

Japan Aquatic Oil Association (ed) (1989) Fatty acid composition of fish and shellfish (In Japanese). Korin Press Inc, Tokyo, p 1-309

Japan Oil Chemists' Society (ed) (1990) Standard methods for the analysis of fats, oils and related materials (in Japanese). Japan Oil Chemists' Society, Tokyo, 2. 4. 20-71

Joseph JD (1989) Distribution and composition of lipids in marine invertebrates. In: Ackman RG (ed) Marine biogenic lipids, fats, and oils, Vol Il. CRC Press Inc, Boca Raton, FL, p 49-144

Kanazawa A, Teshima SI, Ono K (1979) Relationship between essential fatty acid requirements of aquatic animals and the capacity for bioconversion of linolenic acid to highly unsaturated fatty acids. Comp Biochem. Physiol 63B $295-298$

Kattner G, Hirche HJ, Krause M (1989) Spatial variability in lipid composition of calanoid copepods from. Fram Strait, the Arctic. Mar Biol 102:473-480

Kawaguchi K (1977) Micronekton assemblages; myctophid fishes in Suruga Bay. In: Nishizawa S, Ishida R, Kawasaki $\mathrm{K}$ (eds) Biological assemblages and production in the ocean (in Japanese). Koseisha-Koseikaku, Tokyo, p $235-268$

Kinsella JE (1986) Food components with potential therapeutic benefits: the $n-3$ polyunsaturated fatty acids of fish oils Food Technol 40:89-97

Kinsella JE (1988) Food lipids and fatty acids: importance in food quality, nutrition, and health. Food Technol 42: $124-145$

Lee RF, Barnes AT (1975) Lipids in the mesopelagic copepod, Gaussia princeps. Wax ester utilization during starvation. Comp Biochem Physiol 52B:265-268

Lee RF, Hirota J (1973) Wax esters in tropical zooplankton and nekton and the geographical distribution of wax esters in marine copepods. Limnol Oceanogr 18:227-239

Lee RF, Hirota J, Barnett AM (1.971) Distribution and importance of wax esters in marine copepods and other zooplankton. Deep Sea Res 18:11.47-1165

Lee RF, Nevenzel JC, Paffenhöfer GA (1969) Wax esters in marine copepods. Science 167:1510-1511

Lee RF, Patton JS (1989) Alcohols and waxes. In: Ackman RG (ed) Marine biogenic lipids, fats, and oils, Vol l. CRC Press Inc, Boca Raton, FL, p 73-102

Lewis RW (1967) Fatty acid composition of some marine animals from various depths. J Fish Res Bd Can 24:1101-1115

Linko RR, Kaitaranta JK, Vuorela R (1985) Comparison of the fatty acids in baltic herring and available plankton feed Comp Biochem Physiol 82B:699-705

Medina I, Santiago P, Aubourg P, Martin RP (1995) Composition of phospholipids of white muscle of six tuna species. Lipids 30:1127-1135

Mori M. Saito T, Nakanishi Y, Miyazawa $K$, Hashimoto $Y$ (1966) The composition and toxicity of wax in the flesh of castor oil fishes. Bull Jpn Soc Sci Fish 32:137-145

Morris RJ, Culkın F (1989) Fish. In: Ackman RG (ed) Manne biogenic lipids, fats, and oils Vol II. CRC Press Inc, Boca Raton, $\mathrm{FL}_{1}$ p $145-1.78$
Murase T, Saito H (1996) The docosahexaenoic acid content in the lipid of albacore Thunnus alalunga caught in two separate localities. Fish Sci 62:634-638

Nevenzel JC (1969) Occurrence, function and biosynthesis of wax esters in marine organisms. Lipids 5:308-318

Nevenzel JC, Menon N (1980) Lipids of midwater marine fish family Gonostomatidae. Comp Biochem Physiol 65B: $351-355$

Nevenzel JC, Rodegker W, Stephen J, Kayama M (1969) The lipids of some lantern fishes (family Myctophidae). Comp Biochem Physiol 31:25-36

Ohman MD (1987) Energy sources for recruitment of the subantarctic copepod Neocalanus tonsus. Limnol Oceanogr $32: 1317-1330$

Ohman MD, Bradford JM, Jillett JB (1989) Seasonal growth and lipid storage of the circumglobal, subantarctic copepod, Neocalanus tonsus (Brady). Deep Sea Res 36 $1309-1326$

Ohshima T, Wada S, Koizumi C (1989) 1-o-alk-1'-enyl-2-acyl and 1-o-alkyl-2-acyl glycerophospholipids in white muscle of bonito Euthynnus pelamis (Linnaeus). Lipids 24 $363-370$

Ota T, Takagi T, Kosaka S (1980) Changes in lipids of young and adult saury Cololabis saira (Pisces). Mar Ecol Prog Ser 3:11-17

Pascal JC, Ackman RG (1976) Long chain monoethylenic alcohol and acid isomers in lipids of copepods and capelin. Chem Phys Lipids 16:219-223

Patton JS, Nevenzel JC, Benson AA (1975) Specificity of digestive lipases in hydrolysis of wax esters and triglycerides studied in anchovy and other selected fish. Lipids $10: 575-583$

Pearcy WG (1964) Some distributional features of mesopelagic fishes off Oregon. J Mar Res 22:83-102

Pearcy WG, Krygier EE, Mesecar R, Ramsey F (1977) Vertical distribution and migration of oceanic micronekton off Oregon. Deep Sea Res 24:223-245

Raymont JE (ed) (1963) Plankton and productivity in the oceans. Pergamon Press L.td, Oxford

Ratnayake WN, Ackman RG (1979a) Fatty alcohols in capelin, herring and mackerel oils and muscle lipids: I. Fatty alcohol details linking dietary copepod fat with certain fish depot fats. Lipids 14:795-803

Ratnayake WN, Ackman RG (1979b) Fatty alcohols in capelin, herring and mackerel oils and muscle lipids: II. A comparison of fatty acids from wax esters with those of triacylglycerols. Lipids 14:804-810

Ratnayake WN, Ackman RG (1989) Novel branched-chain fatty acids in certain fish oils. Lipids 24:630-637

Rossell JB (1991) Vegetable oils and fats. In: Rossell JB, Pritchard JLR (eds) Analysis of oilseeds, fats and fatty foods. Elsevier Applied Science, London, p 261-327

Saito $H$, Watanabe $T$, Murase $T$ (1995) The fatty acid composition characteristic of a highly migratory fish, with seasonal variation of docosahexaenoic acid content in lipid of bonito (Euthynnus pelamis). Biosci Biotech Biochem 59: $2186-2188$

Sargent JR, Gatten RR, McIntosh R (1977) Wax esters in the marine environment-their occurrence, formation, transformation and ultimate fates. Mar Chem 5:573-584

Sargent JR, Gatten RR, Merrett NR (1983) Lipids of Hoplostethus atlanticus and $H$. mediterraneus (Beryciformes: Trachichthyidae) from deep water to the west of Britain. Mar Biol 74:281-286

Sargent JR, Lee RF (1975) Biosynthesis of lipids in zooplankton from Saanich Inlet, British Columbia, Canada. Mar Biol 31:15-23 
Sargent JR, Parkes RJ, Muller-Harvey I, Henderson, RJ (1988) Lipid biomarkers in marine ecology. In: Sleigh MA (ed) Microbes in the sea. Ellis Horwood Ltd. Chichester, p $119-138$

Stansby ME (1981) Reliability of fatty acid values purporting to represent composition of oil from different species of fish. J Am Oil Chem Soc 58:13-16

St. John MA, Lund T (1996) Lipid biomarkers: linking the utilization of frontal plankton biomass to enhanced condition of juvenile North Sea cod. Mar Ecol Prog Ser 131:75-85

Takagi T, Itabashi Y, Aso S (1985) Fatty acids and fatty alcohols of wax esters in the orange roughy: specific textures of minor polyunsaturated and branched-chain components. Lipids 20:675-679

Takama K, Suzuki T, Yoshida K, Arai H, Anma H (1994) Lipid content and fatty acid composition of phospholipids in white-flesh fish species. Fish Sci 60:177-184

Takeuchi T, Masuda R, Ishizaki Y. Watanabe T, Kanematsu M, Imaizumi K, Tsukamoto K (1996) Determination of the

Editorial responsibility: Otto Kinne (Editor),

Oldendorf/Luhe, Germany requirement of larval striped jack for eicosapentaenoic acid and docosahexaenoic acid using enriched Artemia nauplii. Fish Sci 62:760-765

Tande KS, Henderson RJ (1988) Lipid composition of copepodite stages and adult females of Calanus glacialis in Arctic waters of the Barents Sea. Polar Biol 8:333-339

Taylor FHC (1968) The relationship of midwater trawl catches to sound scattering layers of the coast of northern British Columbia. J Fish Res Bd Can 25:457-472

Teshima S, Kanazawa A, Koshio S (1992) Ability for bioconversion of $\mathrm{n}-3$ fatty acids in fish and crustaceans. Océanis $18: 67-75$

Tyler HR, Pearcy WG (1975) The feeding habits of three species of lantern fishes (family Myctophidae) off Oregon, USA. Mar Biol 32:7-11

Yamada K, Kobayashi K, Yone Y (1980) Conversion of linolenic acid to $\omega$-3-highly unsaturated fatty acids in marine fishes and rainbow trout. Bull Jpn Soc Sci Fish 46 : $1231-1233$

Submitted: April 15, 1997; Accepted: March 5, 1998 Proofs received from author(s): June 18, 1998 